\title{
Identification of Pathogenicity-Related Genes in the Vascular Wilt Fungus Verticillium dahliae by Agrobacterium tumefaciens-Mediated T-DNA Insertional Mutagenesis
}

\author{
K. Maruthachalam • S. J. Klosterman • \\ S. Kang • R. J. Hayes $\cdot$ K. V. Subbarao
}

Published online: 20 March 2011

(c) The Author(s) 2011. This article is published with open access at Springerlink.com

\begin{abstract}
Verticillium dahliae is the causal agent of vascular wilt in many economically important crops worldwide. Identification of genes that control pathogenicity or virulence may suggest targets for alternative control methods for this fungus. In this study, Agrobacterium tumefaciens-mediated transformation (ATMT) was applied for insertional mutagenesis of $V$. dahliae conidia. Southern blot analysis indicated that T-DNAs were inserted randomly into the $V$. dahliae genome and that $69 \%$ of the transformants were the result of single copy T-DNA insertion. DNA sequences flanking T-DNA insertion were isolated through inverse PCR (iPCR), and these sequences were aligned to the genome sequence to identify the genomic position of insertion. $V$. dahliae mutants of particular interest selected based on culture phenotypes included those that had lost the ability to form microsclerotia and subsequently used for virulence assay. Based on the virulence assay of 181 transformants, we identified several mutant strains of $V$. dahliae that did not cause symptoms on lettuce plants. Among these mutants, T-DNA was inserted in genes encoding an endoglucanase 1 (VdEg1), a hydroxyl-methyl glutaryl-CoA synthase (VdHMGS), a major facilitator superfamily 1 (VdMFS1), and a
\end{abstract}

K. Maruthachalam · K. V. Subbarao $(\bowtie)$

Department of Plant Pathology, University of California-Davis, c/o U.S. Agricultural Research Station, 1636 E. Alisal St.,

Salinas, CA 93905, USA

e-mail:kvsubbarao@ucdavis.edu

S. J. Klosterman · R. J. Hayes

USDA-ARS, Salinas, CA 93905, USA

S. Kang

Department of Plant Pathology, The Pennsylvania State University, University Park, PA 16802, USA glycosylphosphatidylinositol (GPI) mannosyltransferase 3 (VdGPIM3). These results suggest that ATMT can effectively be used to identify genes associated with pathogenicity and other functions in $V$. dahliae.

Keywords Verticillium dahliae - Lactuca sativa . ATMT $\cdot$ Pathogenicity related genes

\section{Introduction}

Verticillium wilt disease, caused by the soilborne fungus Verticillium dahliae, is a devastating disease on many economically important crops worldwide [1,2]. Verticillium wilt is particularly difficult to control because the fungus produces melanized structure known as microsclerotia that can survive for years in the soil [1]. Disease control has relied on soil fumigation that has economic and environmental costs inconsistent with sustainable agriculture or the deployment of Verticillium wilt-resistant cultivars that carry the major resistance $(R)$ genes [2]. Effective fungicides have never been available for the control of Verticillium wilt [2]. Furthermore, two distinct races with differential virulence have been described in $V$. dahliae [3-5]. Resistance for race 1 has been identified in tomato and lettuce $[3,4,6]$ but is currently not available for race 2 in either crop. Because of continual immigration of race 2 of $V$. dahliae from exotic sources in some agricultural production regions [5] and the selection for race 2 through deployment of race 1-resistant crops, additional control methods beyond resistance need to be developed.

Verticillium dahliae has evolved mechanisms to expand its host range and overcome various barriers encountered during the infection $[2,7,8]$. A greater understanding of the disease process caused by this fungus is necessary for 
the development of novel disease management methods against Verticillium wilts. Only a few genes required for pathogenicity have been characterized in Verticillium spp. [9-14]. The availability of novel molecular techniques has facilitated the identification and characterization of the genes involved in disease development. Forward genetic approaches such as random insertional mutagenesis provide a unique opportunity to generate genetic mutations in a manner that facilitates subsequent isolation of mutated genes $[15,16]$. The recently released genome sequences of V. dahliae and V. albo-atrum (http://www.broadinstitute. org/annotation/genome/verticillium_dahliae) will be useful for easy identification of T-DNA insertion loci based on detailed genetic blueprints of these pathogens and the potential virulence factors.

Transformation has been particularly useful in the study of fungal genes associated with diverse phenotypes, including pathogenicity and pathogenesis-associated development. In the last three decades, methods such as polyethylene glycol (PEG), restriction enzyme-mediated integration (REMI), and Agrobacterium tumefaciens-mediated transformation (ATMT), have been deployed to transform many fungi $[15,17,18]$ and to conduct largescale genome-wide mutagenesis [16]. Among these methods, ATMT is the most versatile since A. tumefaciens can transform an array of starting materials including protoplasts, hyphae, spores, or blocks of the mycelial tissue $[15,19,20]$. In a recent study, Knight et al. [21] reported the successful application of ATMT to generate random insertional mutants of $V$. albo-atrum. Several studies have also utilized ATMT for targeted gene disruption in Verticillium species [9, 10, 13, 14], but to date, the applicability of random insertional mutagenesis via ATMT for investigating pathogenicity mechanisms in $V$. dahliae has not been evaluated.

The aim of this study was to generate random insertional mutants of $V$. dahliae that have defects in pathogenicity and/or affect the development and survival of this economically important fungus. The results of this study indicate that insertional mutagenesis by ATMT can be a powerful tool for identifying genes involved in these processes.

\section{Materials and Methods}

Fungal and Bacterial Strains

Verticillium dahliae strain VdLs17, for which the whole genome sequence is available (http://www.broadinstitute. org/annotation/genome/verticillium_dahliae), was grown on potato dextrose agar (PDA, Sigma-Aldrich, St. Louis, MO) at $25^{\circ} \mathrm{C}$. Strain VdLs 17 was initially tested for sensitivity to the antibiobtic hygromycin $\mathrm{B}$ at multiple concentrations (ranging from 25 to $125 \mu \mathrm{g} / \mathrm{ml}$ ). A T-DNA binary vector (pSK2241) harboring the hygromycin B resistance gene $(h p h)$ under control of the Aspergillus nidulans trpC promoter and the ZsGreen fluorescent protein gene under control of the Fusarium verticilliodes translation elongation factor $1 \alpha$ gene promoter was used for ATMT. This vector was introduced to A. tumefaciens strain EHA105 to transform conidia of $V$. dahliae.

\section{Transformation}

Although some of the transformation procedures used in this study have already appeared in a previous publication [10], for the sake of completeness, all are described below. A. tumefaciens strain EHA105 was grown at $28^{\circ} \mathrm{C}$ for $48 \mathrm{~h}$ in minimal medium (MM: [22] supplemented with kanamycin $(75 \mu \mathrm{g} / \mathrm{ml})$. Two $\mathrm{ml}$ of this culture was centrifuged at $5,000 \mathrm{rpm}$ for $1 \mathrm{~min}$ to pellet cells. After washing A. tumefaciens cells with induction media (IM: [23], they were resuspended in $5 \mathrm{ml}$ of IM amended with $200 \mu \mathrm{M}$ acetosyringone (AS) and cultured for an additional $6 \mathrm{~h}$ at $28^{\circ} \mathrm{C}$ at $200 \mathrm{rpm}$ on an orbital shaker. Bacterial cells and the conidial suspension of VdLs17 $\left(5 \times 10^{6}\right)$ were mixed (1:1), and $200 \mu \mathrm{l}$ was placed on each nitrocellulose filter $(0.45 \mu \mathrm{m}$-pores and $45 \mathrm{~mm}$ diameter, Whatman) on co-cultivation medium (CM). CM contains the same constituents as IM except that it contains $5 \mathrm{mM}$ of glucose instead of $10 \mathrm{mM}$ of glucose.

Following three different co-cultivation times, including 24,36 , and $48 \mathrm{~h}$ at $28^{\circ} \mathrm{C}$, the nitrocellulose membranes were transferred to selection medium containing hygromycin B $(50 \mu \mathrm{g} / \mathrm{ml})$ as a selection agent for transformants of $V$. dahliae and cefotoxime $(200 \mu \mathrm{g} / \mathrm{ml})$ to eliminate A. tumefaciens cells. Typically, transformants of $V$. dahliae appeared after 5-7 days of incubation. Putative transformants were transferred into 24 well plates (Costar, USA) containing $1.5 \mathrm{ml}$ of PDA with hygromycin B $(50 \mu \mathrm{g} / \mathrm{ml})$ and incubated at $25^{\circ} \mathrm{C}$ for $4-5$ days. After the second selection, conidia of the individual transformants were harvested and re-suspended in sterile distilled water (SDW) and plated on water agar media. To obtain mono-conidial cultures, one germinating conidium from each transformant was plucked and transferred to PDA plates. Transformants were maintained on PDA for routine work. A few transformants were subcultured at least five times on PDA without hygromycin and subsequently transferred to plates containing hygromycin to test the stability of integrated T-DNA. In addition, the fluorescence from ZsGreen was visualized by compound microscope (Olympus BX60), which is equipped with GFP filter (450-490 nm excitation, 500-nm longpass emission), and the system is linked to a CCD device. A Nikon compound microscope with filter 
blocks for GFP (450-490 nm excitation, 590-nm longpass emission), coupled to a MRC1024 Bio-Rad Confocal System (Bio-Rad, Hercules, CA) was used for all confocal laser scanning microscopy (CLSM), and all the settings followed were as previously described [24].

Molecular Analysis of Fungal Transformants

\section{DNA Extraction and PCR Analysis}

To extract fungal DNA for PCR and Southern blot analysis, transformants were grown in $75 \mathrm{ml}$ of Potato Dextrose Broth (PDB) in $250 \mathrm{ml}$ Erlenmeyer flasks at $25^{\circ} \mathrm{C}$ for 5 days. Genomic DNA of individual transformants was extracted from powdered mycelium according to the method of Al-Sammarai and Schmid [25] with the addition of an extra phenol chloroform extraction. The DNA pellet was dissolved in TE solution ( $\mathrm{pH}$ 8.0) and quantified using a NanoDrop 1000 (NanoDrop Products, Wilmington, DE). DNA concentrations were adjusted to $10 \mathrm{ng}$ with SDW for PCR assays. DNA samples were stored at $4^{\circ} \mathrm{C}$ for further use. To verify the integration of T-DNA in the fungal transformants, randomly selected transformants of $V$. dahliae were analyzed by PCR using the $h p h$-specific primers Hy_F (5'-TCA GCT TCG ATG TAG GAG GG-3') and Hy_R (5'-TTC TAC ACA GCC ATC GGT CC-3'). The PCR was carried out in $20 \mu \mathrm{l}$ mixture, which contains 10 ng of genomic DNA, $2 \times$ GoTag master mix (Promega, Madison, WI), 5 pmol of each primer, and the reaction program included $5 \mathrm{~min}$ at $95^{\circ} \mathrm{C} ; 35$ cycles of $1 \mathrm{~min}$ at $95^{\circ} \mathrm{C} ; 1 \mathrm{~min}$ at $60^{\circ} \mathrm{C}$ and $1 \mathrm{~min}$ at $72^{\circ} \mathrm{C}$, and $10 \mathrm{~min}$ at $72^{\circ} \mathrm{C}$ for the final extension. PCR products were separated on a $0.8 \%$ agarose gel stained with ethidium bromide $(\mathrm{EtBr})$ and photographed.

Total RNA of the selected mutants was extracted using the Qiagen RNeasy Plant Mini Kit (Qiagen, La Jolla, CA). For RT-PCR, $1 \mu \mathrm{g}$ of total RNA was reverse-transcribed into first-strand cDNA with oligo dT primer using the SuperScript first-strand synthesis system (Invitrogen, Life Technologies, Carlsbad, CA) according to the manufacturer's instruction. PCR was performed in $50 \mu \mathrm{l}$ reaction mixture containing $5 \mu \mathrm{l}$ of cDNA from each strain, $2 \mu \mathrm{l}$ of dNTP mix, $5 \mu \mathrm{l}$ of $10 \times$ PCR buffer, $6 \mu \mathrm{l}$ of $20 \mathrm{mM} \mathrm{MgCl}_{2}$, $2 \mu \mathrm{l}$ of $5 \mathrm{pmol}$ each primer, $0.5 \mu \mathrm{l}$ of Taq DNA polymerase (5 U/ $\mu \mathrm{l})$ and $27.5 \mu \mathrm{l}$ of SDW. In all, 35 cycles of RT-PCR were run on a Bio-Rad DNA Engine thermocycler (BioRad Laboratories, Hercules, CA).

For detecting transcripts of the five genes, the following primers were used: RTV47F and RTV47R (VDAG_078 25.1), RT021F and RT021R (VDAG_10091.1), RT136F and RT136R (VDAG_09647.1), RT202F and RT202R (VDAG_04078.1), RT235F and RT235R (VDAG_02992.1) and actin VActF and VActR (VDAG_08445.1).

\section{Southern Blot Analysis}

Genomic DNA (approximately $8 \mu \mathrm{g}$ ) from more than 100 putative transformants was digested with EcoRI. The digested DNA (19 samples/run) was separated on a $0.7 \%$ agarose gel, and transferred to a nylon membrane (Roche) using the method described by Selden [26]. The probe was amplified from the $h p h$-coding region using vector pCB1004 as a template [27]. The probe was labeled with digoxigenin (DIG) (Roche, Basel, Switzerland) according to the manufacturer's instructions. Hybridization and detection was performed according to the manufacturer instructions (Roche). X-ray film (Kodak, Rochester, NY) was developed after a $30 \mathrm{~min}$ exposure.

Isolation and Identification of Sequences Flanking T-DNA Insertion Sites

Inverse PCR (iPCR) with modification of the original protocol [28] was used to isolate genomic sequences flanking inserted T-DNA. DNA samples $(2 \mu \mathrm{g})$ from $\sim 100$ transformants were digested with either TaqI or Pst $\mathrm{I}$ restriction enzyme $(5 \mathrm{U})$ for $2 \mathrm{~h}$ at $65^{\circ} \mathrm{C}(\mathrm{TaqI})$ or overnight at $37^{\circ} \mathrm{C}($ PstI $)$ in $50 \mu \mathrm{l}$ reactions. Digested DNA was purified by phenol-chloroform extraction and ethanol precipitated. The DNA pellet was dissolved in $40 \mu \mathrm{l}$ SDW, and the digested DNA (100 ng) was ligated at $16^{\circ} \mathrm{C}$ for $5 \mathrm{~h}$ using T4 DNA ligase (Promega, Madison, WI).

iPCR was carried out with ligated DNA as a template. PCR was carried out in $20 \mu \mathrm{l}$ reactions containing $3 \mu \mathrm{l}$ of ligated genomic DNA, $2 \mu \mathrm{l}$ of $10 \times$ PCR buffer, $2 \mu \mathrm{l}$ of dNTP mixture, $1 \mu$ of each RB3 (5'-CCCTTCCCAACA GTTGCGCA-3') and RBn1 primers (5'-TTACAACGTCG TGACTGGGAAAAC- $3^{\prime}$ ) and $0.2 \mu \mathrm{l}$ of Taq DNA polymerase (Promega, Madison, WI) and $10.8 \mu \mathrm{l}$ of SDW. EXOSAP-IT (Affymetrix/USB, Cleveland, $\mathrm{OH}$ ) was applied to the PCR products to eliminate unincorporated primers and used for direct sequencing. Sequencing was carried out using the RB3 primer at the University of California-Davis CAES Genomics Facility (Davis, CA), using an automated ABI 3730 DNA analyzer (Applied Biosystems, Foster City, CA).

Resulting sequences were used as queries to search the Verticillium Group Database at the Broad Institute (http:// www.broadinstitute.org/annotation/genome/verticillium dahliae) and the National Center for Biotechnology Information (NCBI) websites (http://www.ncbi.nlm.nih.gov) via the Blastn and Blastx algorithms.

\section{Phenotype Characterization}

To study the colony morphology, the transformants were grown on PDA for 10 days and then growth rates (based on 
Table 1 Proportion of symptomatic leaves based on the first round of pathogenicity screening of transformants using soilless Verticillium wilt assay

\begin{tabular}{|c|c|c|c|c|c|c|c|c|c|c|}
\hline \multirow[t]{3}{*}{ Experiment } & \multicolumn{10}{|c|}{ Proportion of symptomatic leaves ${ }^{a}$} \\
\hline & \multirow{2}{*}{$\begin{array}{l}\text { Wild type } \\
\text { mean }\end{array}$} & \multirow[t]{2}{*}{ Water mean } & \multirow{2}{*}{$\begin{array}{l}\text { Population } \\
\text { means }\end{array}$} & \multicolumn{7}{|c|}{ Number of isolates } \\
\hline & & & & 0.00 & $0.01-0.20$ & $0.21-0.40$ & $0.41-0.60$ & $0.61-0.80$ & $0.81-1.0$ & Total \\
\hline Unreplicated screen & 0.41 & 0.13 & 0.35 & 20 & 31 & 54 & 63 & 13 & 0 & 181 \\
\hline
\end{tabular}

${ }^{a}$ Proportion of symptomatic leaves was calculated from a total of three plants for each isolate and the water control

Table 2 Foliar disease rating and proportion of plants with root vascular discoloration of lettuce plants inoculated with four insertional mutants of Verticillium dahliae

\begin{tabular}{|c|c|c|c|c|c|c|c|c|}
\hline \multirow[t]{3}{*}{ Treatment } & \multirow{3}{*}{$\begin{array}{l}\text { Number of } \\
\text { plants tested }\end{array}$} & \multicolumn{4}{|c|}{ Proportion root discoloration } & \multicolumn{3}{|c|}{ Foliar disease rating $^{\mathrm{b}}$} \\
\hline & & \multirow[t]{2}{*}{ Median } & \multirow[t]{2}{*}{$\mathrm{RME}^{\mathrm{a}}$} & \multicolumn{2}{|c|}{$95 \%$ confidence interval } & \multirow[t]{2}{*}{ Mean } & \multicolumn{2}{|c|}{$99.9 \%$ confidence interval } \\
\hline & & & & Lower bound & Upper bound & & Lower bound & Upper bound \\
\hline VdLs.17 (WT) & 18 & 0.83 & 0.80 & 0.55 & 0.89 & 0.64 & 0.35 & 0.91 \\
\hline VdATMT-V47 & 18 & 0.17 & 0.36 & 0.24 & 0.52 & 0.07 & 0.04 & 0.12 \\
\hline VdATMT-020 & 18 & 0.83 & 0.72 & 0.55 & 0.83 & 0.56 & 0.28 & 0.85 \\
\hline VdATMT-021 & 18 & 0 & 0.19 & 0.14 & 0.29 & 0.05 & 0.03 & 0.09 \\
\hline VdATMT-036 & 18 & 0.83 & 0.73 & 0.43 & 0.87 & 0.48 & 0.22 & 0.77 \\
\hline Water control & 18 & 0 & 0.19 & 0.14 & 0.29 & 0.04 & 0.02 & 0.05 \\
\hline
\end{tabular}

${ }^{a}$ The relative marginal effect (RME) and 95\% confidence intervals were calculated from the analysis of rank values of the root vascular discoloration data

${ }^{b}$ Disease ratings are the backtransformed values from analysis of arcsine-transformed proportion symptomatic leaves data. Higher values indicate higher percentage of symptomatic leaves

colony diameters measured once a week over a 2-week period) of individual transformants were measured and compared with wild-type strain VdLs17. Similarly, their microsclerotia production was compared with that of VdLs17 (the number of microsclerotia in three microscopic fields were counted and averaged). Based on these phenotypic characters, we selected those mutants that had varied phenotypes compared with wild-type strain VdLs17 and used for pathogenicity assay. Soilless virulence assays on lettuce (Lactuca sativa) cultivar PI 251246 were conducted as previously described [29]. For virulence assay, conidia of individual transformants were harvested from PDA plates and conidial density was adjusted to $1 \times 10^{7}$ conidia/ml. We screened 181 mutants (Table 1), inoculating three plants per mutant. Inoculated plants were incubated in a Conviron E15 growth chamber set to 16-h light/ 8 -h dark cycles at $25^{\circ} \mathrm{C}$. Three plants were inoculated with wild-type strain VdLs17 served as inoculated control plants, and three plants mock inoculated with SDW served as uninoculated control plants for virulence assay. Three weeks after inoculation, leaf and root symptoms were observed and recorded as described in Klosterman and Hayes [29].

The pathogenicity assay was repeated for those mutants that exhibited reduced virulence or were a putative nonpathogenic mutant (four mutants). Each mutant was tested in three replicate experiments with six plants per experiment per mutant (Table 2). Inoculated plants were spaced in rows of six plants in a foam container (Fig. 3a). The proportion of symptomatic leaves was recorded for each plant, and the percentage of plants with root discoloration was recorded for each mutant in each replicate experiment. Proportion symptomatic leaves data was totaled for each mutant in each experiment, arcsine-transformed, and analyzed in Proc Mixed of SAS (Version 9.2) with mutant and experiment as fixed effects. Least square means and $99.9 \%$ confidence interval were determined for each mutant, and means with non-overlapping confidence intervals were considered to be significantly different. Means and confidence intervals were backtransformed and reported as disease rating (DR) in the table. Root discoloration data were analyzed using analysis of variance (ANOVA)-type statistics of ranked data using the PROC Mixed procedure of SAS. The LD_CI macro was used to generate relative marginal effects (RME) for each mutant and $95 \%$ confidence intervals for detection of statistical differences between treatments [30, 31]. RME with nonoverlapping confidence intervals were considered to be significantly different. Median root discoloration for each mutant was calculated. 


\section{Results}

\section{ATMT of $V$. dahliae}

Hygromycin B sensitivity of VdLs17 was evaluated by growth on PDA amended with different concentrations of hygromycin B (up to $125 \mu \mathrm{g} / \mathrm{ml}$ ). Growth was completely inhibited at $50 \mu \mathrm{g} / \mathrm{ml}$ hygromycin B. (Fig. 1a), and this concentration was used to select transformants. A. tumefaciens strain EHA 105 carrying binary vector pSK2241, which carries the $h p h$ and ZsGreen genes in the T-DNA, was used for the transformation of $V$. dahliae. First, cocultivation time for ATMT was evaluated to optimize insertional mutagenesis. Specifically, the transformation efficiency and the copy number of T-DNA in individual transformants were examined in relation to the length of the co-cultivation period. Among the three different cocultivation periods with $5 \times 10^{6}$ spore concentration, $36 \mathrm{~h}$ was found to be optimal. After $36 \mathrm{~h}$ of co-cultivation, 80-105 transformants per plate were obtained, and after $48 \mathrm{~h}$, an additional 125-150 transformants per plate (Fig. 1b) were obtained, but the frequency of single copy integration of the T-DNA decreased. Prolonged co-cultivation $(>48 \mathrm{~h})$ led to excessive mycelial growth, confounding identification of individual transformants. No transformants were obtained using co-cultivation media without AS, confirming that AS is essential for A. tumefaciens transformation of $V$. dahliae (data not shown).

Five randomly selected $V$. dahliae transformants were subcultured for five successive generations in the absence of hygromycin B and screened for hygromycin B resistance and green fluorescence in the sixth generation. All the transformants remained resistant to hygromycin B (data not shown) and exhibited stable green florescence (Fig. 1c), confirming stability of the transformants.

\section{Integration of T-DNA into Fungal Genomic DNA}

The integration of the $h p h$ gene in the monoconidial colonies of the transformants was initially ascertained by PCR. PCR amplification of this gene from 100 putative transformants confirmed its presence in the genome of all transformants, whereas no product was amplified from the wild type (data not shown).

To further verify the integration of T-DNA and to assess the copy number of T-DNA in the genome, randomly selected transformants were analyzed by Southern hybridization using an $h p h$ probe (see "Materials and Methods" section). About $69 \%$ of transformants harbored a single insert of T-DNA (Fig. 2a). After $24 \mathrm{~h}$ of co-cultivation, 12 out of the 17 transformants had a single T-DNA insert with the site of insertion appearing to vary among transformants
Fig. 1 Agrobacterium tumefaciens-mediated transformation of Verticillium dahliae. a Hygromycin B sensitivity of $V$. dahliae strain VdLs17. b Individual colonies of transformants appearing on nylon membrane after 48 -h co-cultivation and selection on a medium containing hygromycin B. c Expression of green fluorescent protein in conidia of $V$. dahliae transformant (VdATMT-316) was analyzed by compound microscope. c Scale bar $=100 \mu \mathrm{m}$

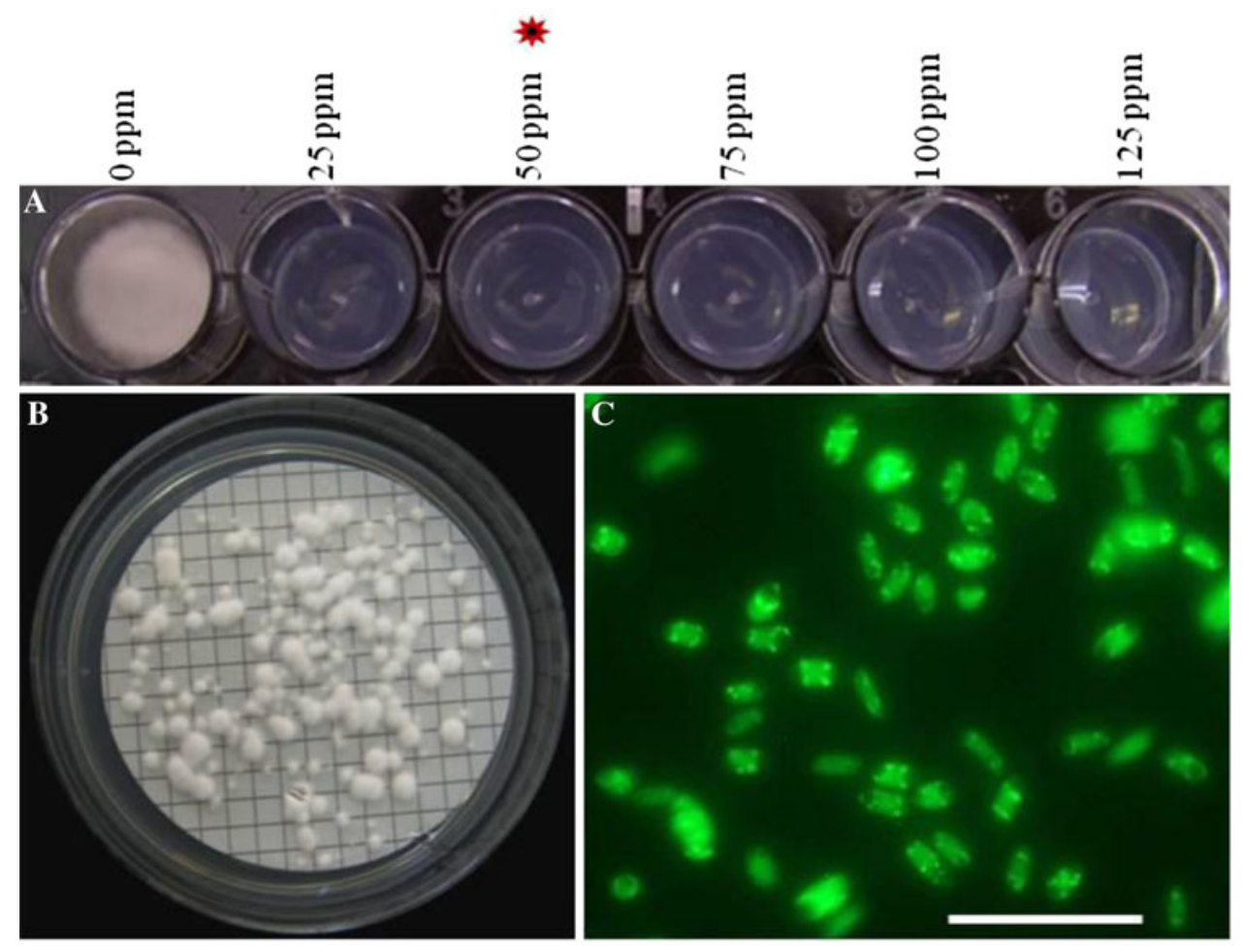


Fig. 2 T-DNA copy number analysis in Verticillium dahliae transformants. a Southern blot analysis of T-DNA integration for randomly selected $V$. dahliae transformants. Genomic DNA was digested with EcoRI, separated on $0.7 \%$ agarose gel, transferred to a nylon membrane (Roche), and hybridized with a digoxigenin-labeled $1.4 \mathrm{~kb}$ fragment of $h p h$. Lanes 1-21 transformants of strain VdLs17, WT wild-type strain VdLs17. b Analysis of T-DNA copy number at differing co-cultivation times of 24, 36, and $48 \mathrm{~h}$

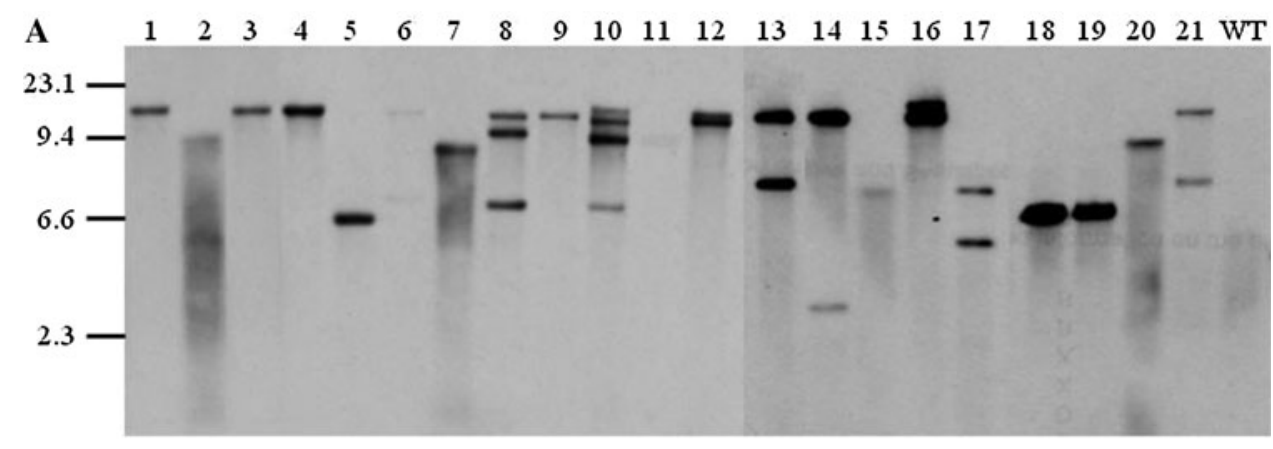

B

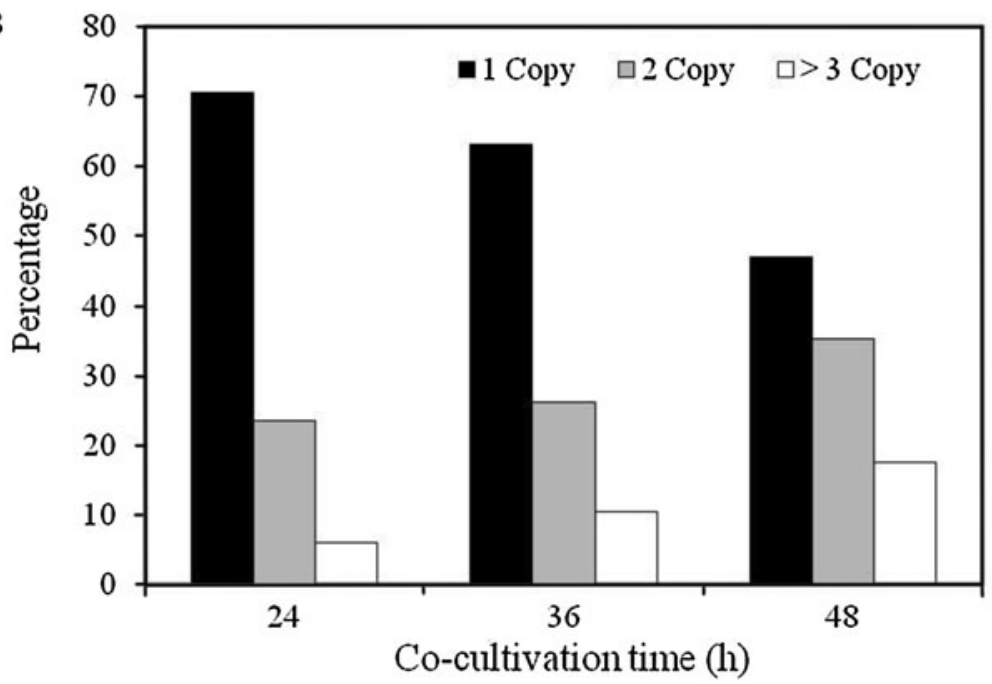

(Fig. 2a; Table 3). Four transformants had two T-DNA insertions, and one had three insertions (Fig. 2b).

\section{Pathogenicity Assay}

We screened 181 transformants for changes in virulence using a soilless Verticillium wilt assay [29] with lettuce cultivar PI 251246. This assay enabled the testing of 100 transformants in a single experiment (Fig. 3). These 181 transformants were selected for their interesting phenotypes, such as defects in growth, colony color, and reduced microsclerotia production (data not shown), and a few of the representative phenotypes are displayed in Fig. 4. Of the 181 transformants assayed, many caused severe necrosis, wilting of leaves, and root discoloration comparable to the symptoms associated with infection caused by the wild-type strain VdLs17 (Table 1). However, about 20 transformants showed no virulence, and 31 transformants exhibited reduced virulence relative to the wild-type strain. Among the 20 mutants potentially defective for pathogenicity identified in the first round of screening, we selected four mutants that caused no symptoms and tested these further using 18 plants (six plants/replication). Among these four, two (insertional mutants VdATMT-V47 and VdATMT021) were nonpathogenic (Table 2) and interestingly, the mutant VdATMT-V47 did not produce microsclerotia on PDA plates (Fig. 5g). In addition, VdATMT-V47 did not colonize the xylem vessels (Fig. $5 \mathrm{~h}-\mathrm{j}$ ). Similarly, no vascular colonization was observed in VdATMT-021 inoculated plant, and this mutant produced less microsclerotia on PDA plate (Fig. 5c-f). The mutants, VdATMT-21 and VdATMT-V47, showed neither necrosis (mean foliar DR, $0.05,0.07)$ nor significant root discoloration (0 and $11 \%$ ) on lettuce relative to water control (0.04 mean foliar DR and root discoloration $0 \%$ ). The remaining two mutants (VdATMT-020 and VdATMT-036) appeared to be false positive, because they were comparable to the wild-type strain in foliar DR (Table 2).

The other two mutants, VdATMT-136 and VdATMT235, used for confocal microscopic study to compare VdATMT-V47 and VdATMT-021 mutants virulence phenotypes, caused weak (VdATMT-136) or intense colonization (VdATMT-235) on inoculated plants (Fig. 51-n, p-r).

\section{Identification of the Genes Tagged by T-DNA Insertions Using iPCR}

iPCR is a rapid and an efficient tool for isolating sequences adjacent to inserted T-DNA in the transformants of fungal species $[32,33]$. For iPCR amplification of genomic DNA 
Table 3 Sequence analysis of T-DNA flanking regions of Verticillium dahliae transformants using Verticillium group and NCBI databases

\begin{tabular}{|c|c|c|c|c|c|}
\hline Transformant & $\begin{array}{l}\text { T-DNA } \\
\text { copy no }\end{array}$ & BLAST hit & Locus & E-value & Chromosome \\
\hline VdATMT-005 & 2 & Predicted protein & VDAG_02684.1 & $1.20289 \mathrm{E}-20$ & 3 \\
\hline VdATMT-018 & 1 & $\begin{array}{l}\text { Transmembrane and coiled-coil } \\
\text { domain-containing protein }\end{array}$ & VDAG_03258.1 & 0.0 & 6 \\
\hline VdATMT-021 & 2 & $\begin{array}{l}\text { Hydroxymethylglutaryl-CoA } \\
\text { synthase }\end{array}$ & VDAG_10091.1 & 0.0 & 1 \\
\hline VdATMT-025 & 2 & $\begin{array}{l}\text { Cytochrome oxidase subunit } \\
\text { I_Mitochondria }\end{array}$ & VDAG_17012.1 & $1.43385 \mathrm{E}-7$ & Mitochondria \\
\hline VdATMT-030 & 1 & $\begin{array}{l}\text { F-actin-capping protein subunit } \\
\text { alpha }\end{array}$ & VDAG_01574.1 & 0.0 & 1 \\
\hline VdATMT-V47 & 1 & Endoglucanase EG-1 & VDAG_07825.1 & 0.0 & 2 \\
\hline VdATMT-048 & 2 & $\begin{array}{l}\text { Choline/ } \\
\text { ethanolaminephosphotransferase }\end{array}$ & VDAG_02561.1 & 0.0 & 3 \\
\hline VdATMT-070 & 4 & $\begin{array}{l}\text { Aromatic amino acid } \\
\text { aminotransferase }\end{array}$ & VDAG_01337.1 & 0.0 & 1 \\
\hline VdATMT-084 & 1 & Conserved hypothetical protein & VDAG_01624.1 & 0.0 & 1 \\
\hline VdATMT-094 & 2 & Conserved hypothetical protein & VDAG_03742.1 & 0.0 & 3 \\
\hline VdATMT-100 & 4 & $\begin{array}{l}\text { NAD }(\mathrm{P}) \mathrm{H} \text {-dependent } \mathrm{D} \text {-xylose } \\
\text { reductase }\end{array}$ & VDAG_01073.1 & 0.0 & 1 \\
\hline VdATMT-111 & ND & Intergenic region & ND & $1.31368 \mathrm{E}-35$ & ND \\
\hline VdATMT-118 & 1 & $\begin{array}{l}\text { C6 Zinc finger domain-containing } \\
\text { protein }\end{array}$ & VDAG_08079.1 & 0.0 & 6 \\
\hline VdATMT-136 & 1 & $\begin{array}{l}\text { Major facilitator super family } \\
\text { (MFS) transporter }\end{array}$ & VDAG_09647.1 & 0.0 & 7 \\
\hline VdATMT-141 & ND & Cytochrome b5 & VDAG_01573.1 & 0.0 & 1 \\
\hline VdATMT-145 & 2 & Intergenic region & ND & 0.0 & 2 \\
\hline VdATMT-156 & ND & Conserved hypothetical protein & VDAG_02688.1 & 0.0 & 3 \\
\hline VdATMT-184 & 2 & Conserved hypothetical protein & VDAG_01624.1 & & 1 \\
\hline VdATMT-202 & 1 & Ras GTPase activator & VDAG_04078.1 & $2.98277 \mathrm{E}-14$ & 3 \\
\hline VdATMT-212 & 2 & Hypothetical protein & VDAG_00726.1 & 0.0 & 2 \\
\hline VdATMT-220 & 1 & Transcriptional activator SPT7 & VDAG_00822.1 & 0.0 & 1 \\
\hline VdATMT-223 & 1 & Intergenic region & ND & $3.21862 \mathrm{E}-29$ & 3 \\
\hline VdATMT-224 & 2 & Intergenic region & ND & $3.73693 \mathrm{E}-7$ & 4 \\
\hline VdATMT-235 & 1 & Prolyl-tRNA synthetase & VDAG_02992.1 & 0.0 & 6 \\
\hline VdATMT-236 & 1 & Intergenic region & ND & $1.28399 \mathrm{E}-28$ & 3 \\
\hline VdATMT-239 & 1 & Predicted protein & VDAG_03441.1 & 1.91778E-20 & 6 \\
\hline VdATMT-240 & 1 & Conserved hypothetical protein & VDAG_09053.1 & 0.0 & 5 \\
\hline VdATMT-245 & ND & GPI mannosyltransferase & VDAG_05742.1 & 0.0 & 4 \\
\hline VdATMT-255 & 1 & Choline dehydrogenase & VDAG_03611.1 & $6.21806 \mathrm{E}-32$ & 3 \\
\hline VdATMT-256 & 1 & Intergenic region & ND & 0.0 & 3 \\
\hline VdATMT-264 & 1 & Intergenic region & ND & 0.0 & 2 \\
\hline VdATMT-279 & 1 & $\begin{array}{l}\text { Fungal-specific transcription factor } \\
\text { domain-containing protein }\end{array}$ & VDAG_08521.1 & 0.0 & 2 \\
\hline VdATMT-303 & 2 & Conserved hypothetical protein & VDAG_01611.1 & $1.60958 \mathrm{E}-29$ & 1 \\
\hline VdATMT-314 & ND & $\begin{array}{l}\text { Type I inositol-1,4,5-triphosphate } \\
\text { 5-phosphatase CVP2 }\end{array}$ & VDAG_01273.1 & 0.0 & 1 \\
\hline VdATMT-316 & ND & Membrane protein & VDAG_05753.1 & 4.27732E-21 & 4 \\
\hline VdATMT-320 & ND & Conserved hypothetical protein & VDAG_02295.1 & $3.58475 \mathrm{E}-34$ & 7 \\
\hline
\end{tabular}

$N D$ not determined 

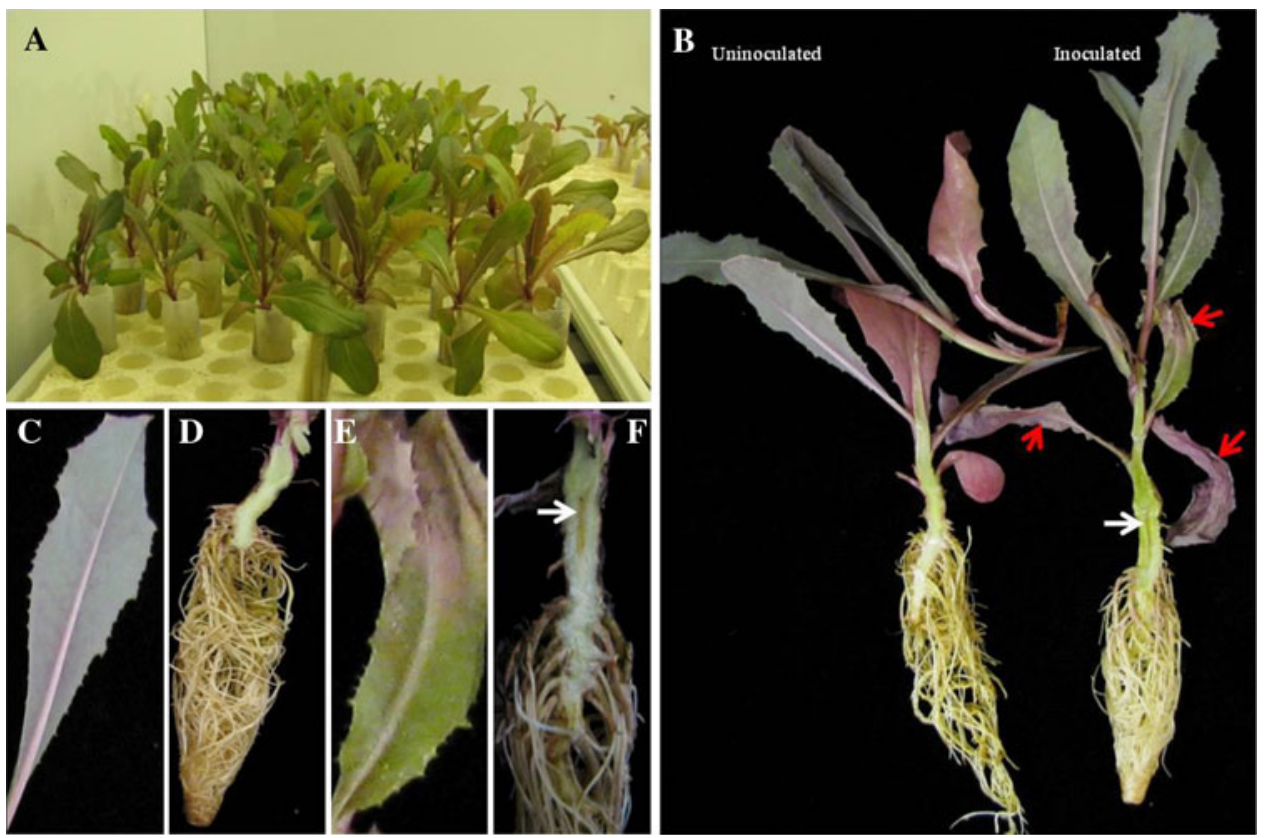

Fig. 3 Application of a soilless Verticillium wilt assay using the early flowering lettuce cultivar, PI 251246, to assess the virulence of strains of Verticillium dahliae transformed by random insertional mutagenesis. a Falcon tubes containing lettuce seedlings were inoculated with $1 \times 10^{7}$ spore concentrations of individual transformants arranged in foam insulated trays and kept in a growth chamber for 3 weeks at

flanking the T-DNA insertion site, we used two primers, RB3 and RBn1, which are designed to amplify the right T-DNA border sequence and adjacent sequence from $V$. dahliae. Sequences of amplified iPCR products were used for searching the Verticillium group genome database, and the NCBI database using Blastn and Blastx algorithms [34] to identify T-DNA insertion site.

Analysis of 36 mutants by iPCR sequences revealed that the genes tagged by T-DNA may have roles in toxin efflux, plant cell wall degradation, and other processes that could contribute to virulence (Table 3). In one of the mutants, VdATMT-136, the T-DNA was inserted in a gene encoding a major facilitator superfamily (MFS) transporter (VDAG_ 09647.1). In mutant VdATMT-245, the T-DNA was inserted in a gene GPI mannosyltransferase (VDAG_05742.1). Other genes included endoglucanase 1 (VDAG_07825.1), a transmembrane and coiled coil domain containing protein (VDAG_03258.1), a hydroxymethylglutaryl-CoA synthase (VDAG_10091.1), a C6 Zinc finger domain containing protein (VDAG_008079.1), and a Ras GTPase activator (VDAG_04078.1) (Table 3). The T-DNA was also inserted in genes encoding hypothetical proteins, some of which may have novel functions (Table 3). Importantly, analyses of sequences near the T-DNA integration sites suggested that T-DNA insertions were unbiased, since the integrations were scattered on seven of the eight chromosomes of $V$. dahliae (Table 3). $25^{\circ} \mathrm{C}$. b Inoculated plant showing symptoms of vascular wilt disease 21 days after inoculation. Uninoculated plant (left) did not show Verticillium wilt symptoms. White arrow indicates brownish root discoloration and red arrows indicate symptomatic leaves showing necrosis and wilting. A representative healthy leaf (c), healthy root (d) and symptomatic leaf (e) and symptomatic root tissue (f)

The right border of inserted T-DNA and its flanking genomic sequences were analyzed to determine how T-DNA was integrated in the mutants using Verticillium group database and the NCBI GenBank database. Out of 23 insertion sites analyzed, there was no T-DNA sequence truncation in 19 of them $(\sim 80 \%)$. The maximum truncation was two nucleotides in one site (Fig. 6).

\section{RT-PCR on T-DNA Mutated Genes}

RT-PCR was carried out on five different genes affected by the T-DNA insertion. The results revealed that the transcripts of these five genes that encode endoglucanase 1 (VdEg-1), hydroxyl-methyl glutaryl-CoA synthase (VdHMGS), a major facilitator superfamily transporter 1 (VdMFS1), Ras GTPase activator (VdRasGAP), and a Prolyl-tRNA synthetase $(V d P t R S)$ were not detected in the T-DNA mutants, and all these five genes transcripts were present in the wilt-type strain, VdLs17 (Fig. 7).

\section{Discussion}

The principal aim of this study was to generate random insertional mutants in $V$. dahliae using ATMT. In recent years, this approach has been applied to several fungi to generate mutants and subsequently indentify mutated genes 
Fig. 4 Representative T-DNA insertional mutants of

Verticillium dahliae examined for colony growth

characteristics, and the ability to form microsclerotia on PDA medium
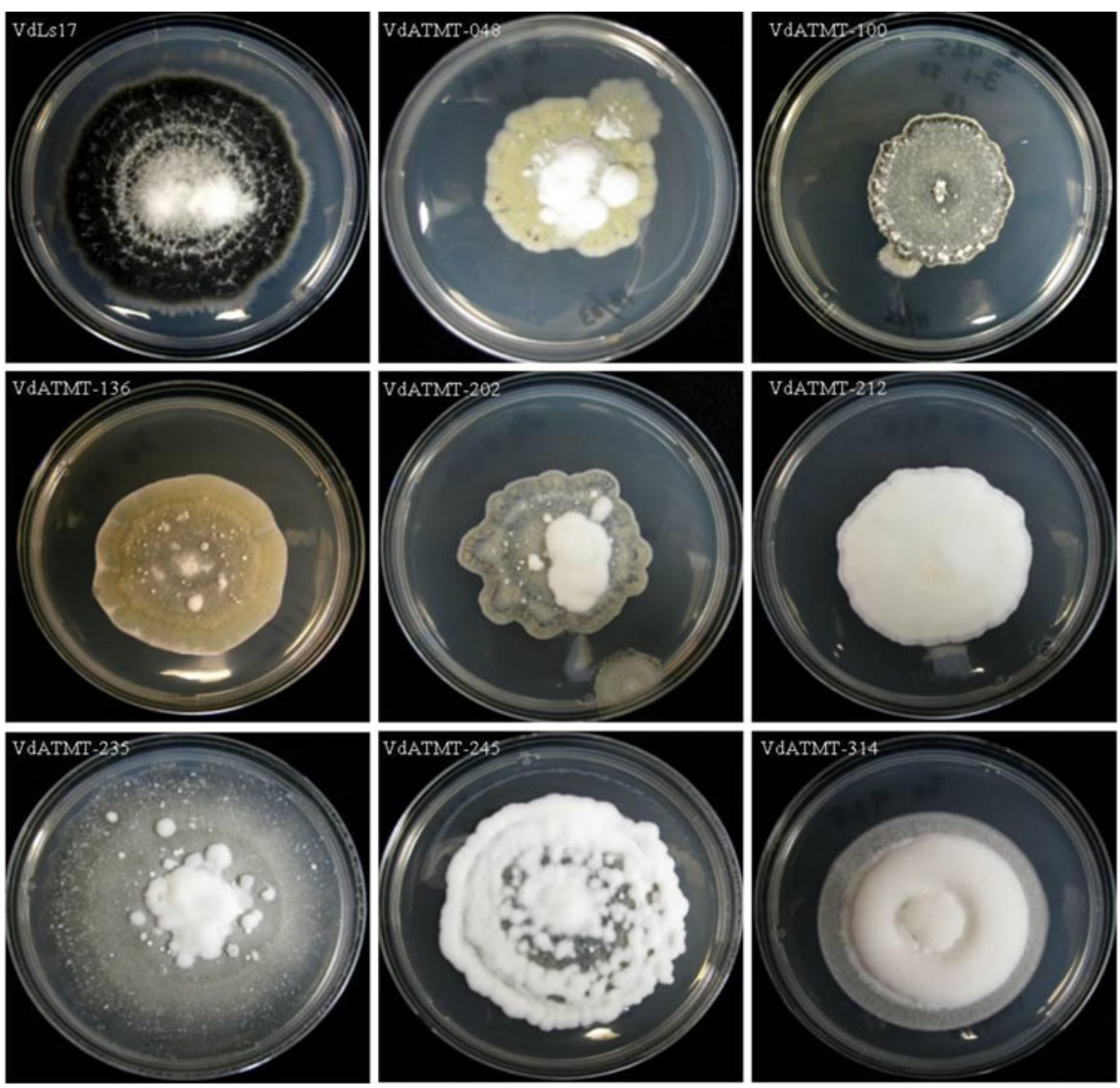

$[15,16]$. ATMT has several advantages compared with other transformation methods, mainly because of the versatility in selecting starting material, transformation efficiency, and high percentage of single copy T-DNA integration [15]. Using ATMT, genome-wide analysis of pathogenicity genes has been carried out in Magnaporthe oryzae [16].

ATMT has been exploited for random and targeted mutagenesis in many foliar fungal pathogens, but comparable studies with soilborne fungal pathogens lag behind. Therefore, development and implementation of an ATMT protocol for insertional mutagenesis of the soilborne pathogen $V$. dahliae represents an important step to characterize genes involved in pathogenicity and survival of soilborne fungi. We used a soilless Verticillium wilt assay to screen 181 mutants for changes in virulence. This assay is preferred because it is rapid compared with the conventional greenhouse assay in the soil medium (takes $\sim 16$ weeks) [29]. The soilless assay enabled the testing of 100 transformants in a single experiment. Many transformants $(\sim 60 \%)$ caused necrosis, wilting, and root discoloration similar to control plants inoculated with the wild-type strain. However, several mutants showed an altered pathogenicity phenotype on lettuce, including several mutant strains, which completely lost or had reduced virulence relative to the wild-type strain. T-DNA insertion in two of these loci eliminated or reduced the ability of these mutants to cause disease. In this study, we report a high frequency of isolating pathogenicity/virulence-defective mutants compared with other fungi [16, 35], because these mutants selected for pathogenicity assay showed interesting phenotypes on PDA medium, such as slow and fluffy growth, different colony color, and few or no microsclerotia production.

Among the genes identified through ATMT insertional mutagenesis, two had an insertion in genes that had previously been characterized and known to be involved in pathogenicity in other fungi and bacteria [36-40, 42, 43]. The flanking sequence from one of the mutants, VdATMTV47, demonstrated that the T-DNA insertion was in predicted endoglucanase $E G-1$ gene in $V$. dahliae (VDAG 07825.1). Microscopic observations suggest that this mutant was unable to colonize the xylem vessels in inoculated plants. Plant pathogenic fungi, including $V$. dahliae, are known to produce a range of cell wall-degrading enzymes to facilitate infection and colonization [1]. Endoglucanase 1 $(E G-1)$ is important for the depolymerization of plant cellulose [36, 37]. Deletion of major endoglucanase genes in phytopathogenic bacteria resulted in reduction or loss 


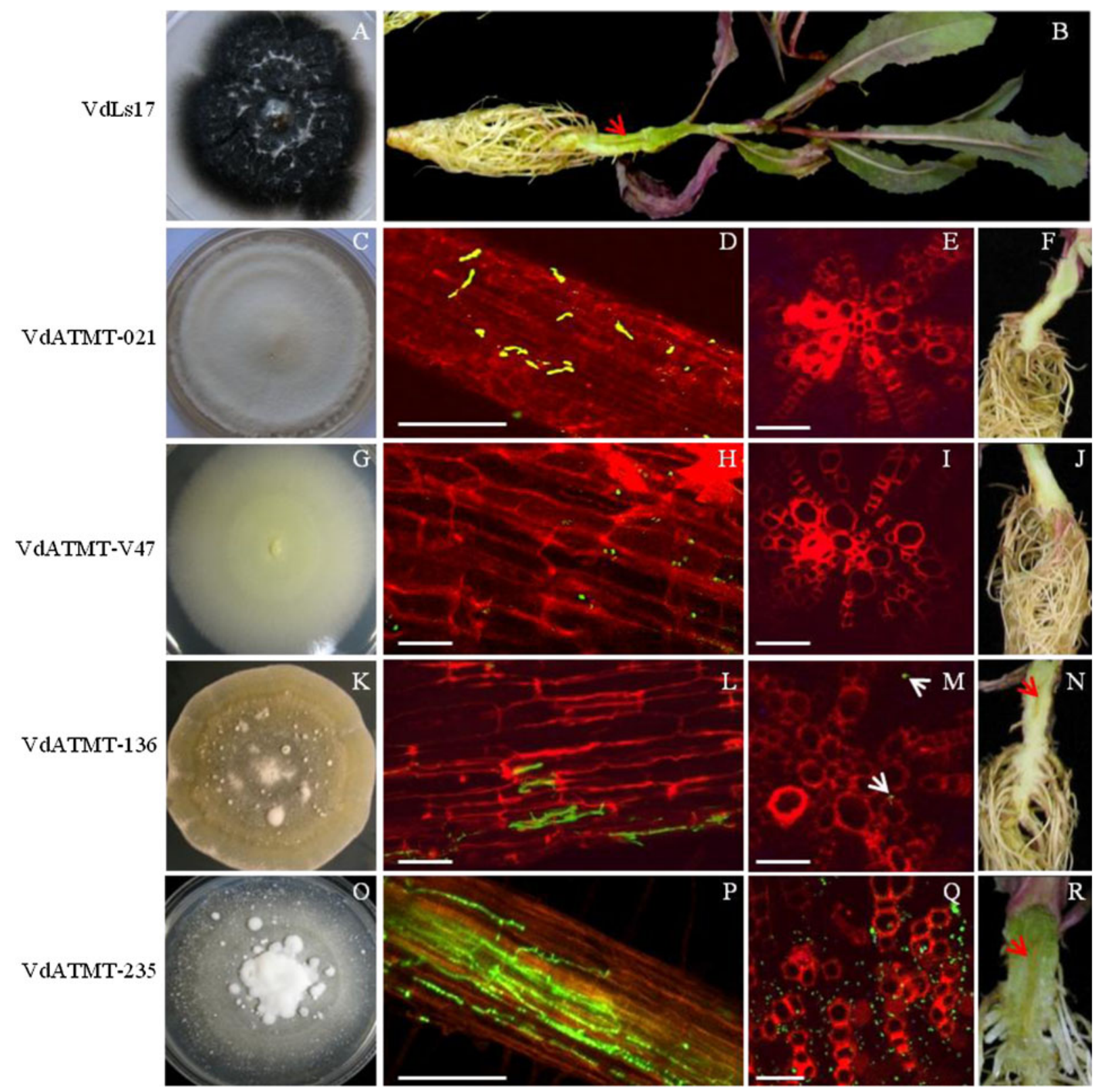

Fig. 5 Pathogenicity of VdLs17, VdATMT-021, VdATMT-V47, VdATMT-136, and VdATMT-235. Lettuce cultivar PI 251246 was inoculated by soilless Verticillium assay using conidial suspension $\left(5 \times 10^{6}\right)$ of the mutants and wild-type strain VdLs17. Part of images was captured using CLSM. a, c, g, k, o The cultures phenotype during growth on potato dextrose agar. b Plant inoculated with VdLs17 showing symptoms of vascular wilt disease 21 days after inoculation. d Conidia of VdATMT-021 were showing delayed germination on the lateral roots. e Cross section of main root showing no colonization of VdATMT-021 mutant-inoculated plant, 3 weeks after inoculation. f Vascular discoloration was not observed in ATMT-021 mutantinoculated plant root system. h Conidia of the VdATMT-V47 mutant were trying to germinate on the lateral roots, 2 weeks after inoculation. i Cross section of main root showing no colonization

of virulence $[38,39]$. In $V$. dahliae, higher endo- $\beta$-1,4-glucanase activity was correlated with aggressiveness [40]. Thus, the predicted $E G-1$ in $V$. dahliae $(V d E g-1)$ plays an of VdATMT-V47 mutant-inoculated plant, 3 weeks after inoculation. j Vascular discoloration was not observed in VdATMT-V47 mutantinoculated plant root system. I Mutant VdATMT-136 showing less colonization on lateral root, 2 weeks after inoculation. m Cross section of main root showing less colonization of VdATMT-136 in the xylem of the plant. $\mathbf{n}$ Less vascular discoloration was observed in ATMT-136 mutant-inoculated root system. p Intense colonization of VdATMT-235 on lateral root system, 2 weeks after inoculation. q Cross section of main root showing intense colonization of VdATMT-235 in the xylem of the plant. $\mathbf{r}$ Vascular discoloration of the taproot of the plant inoculated with VdATMT-235. d, h, l, p Scale bars $=100 \mu \mathrm{m} ; \mathbf{e}, \mathbf{i}, \mathbf{m}, \mathbf{q}$ Scale bars $=50 \mu \mathrm{m}$. Red and white arrowheads indicate the site of root colonization and vascular discoloration

important role in plant penetration or in early stages of colonization. A detailed characterization of endoglucanase 1 in $V$. dahliae is currently underway. 


\begin{abstract}
VdATMT094: CAGATTGTCGTTTCCCGCCTTCAGTTTAAACTATCAGTGTTTGAccaccgataaggaatcgaagaccgctggagtgctgccagctgcaacg
T-DNA cleavage site VdATMT111: CAGATTGTCGTTTCCCGCCTTCAGTTTAAACTATCAGTGTTTGAgagcgagagagagcctcctattcccgagccgcccgccaactacgccac VdATMT145: CAGATTGTCGTTTCCCGCCTTCAGTTTAAACTATCAGTGTTTGActtaaggccgagtcgtaggcaacagtacatcgtcaatgtcttgggtta VdATMT156: CAGATTGTCGTTTCCCGCCTTCAGTTTAAACTATCAGTGTTTGAcgctggtagtgcacaggcttgtcatcatgcgagagccgaaacagctcc VdATMT184: CAGATTGTCGTTTCCCGCCTTCAGTTTAAACTATCAGTGTTTGAcggccactctccggcgcatccetgggcgacttgcagcgcaggggcgta VdATMT202: CAGATTGTCGTTTCCCGCCTTCAGTTTAAACTATCAGTGTTTGAccaagaaggttataggaagctagccttagaacatcgtcgaatcaaac VdATMT212: CAGATTGTCGTTTCCCGCCTTCAGTTTAAACTATCAGTGTTTGAggtaaggtgactacgtacgtacatgtacgtatagagttggggtaaag VdATMT220: CAGATTGTCGTTTCCCGCCTTCAGTTTAAACTATCAGTGTTTGAcccegccagccaatcccacgcacctcaagcaccacgtaccacacgcac VdATMT223: CAGATTGTCGTTTCCCGCCTTCAGTTTAAACTATCAGTGTTTGAcccctgaccaaattttgtttctctcgaggcaaatgctagacgacctgt VdATMT224: CAGATTGTCGTTTCCCGCCTTCAGTTTAAACTATCAGTGTTTGAaggcgtctgacgagggatggactcgaatcaaactgctagatatacctg VdATMT236: CAGATTGTCGTTTCCCGCCTTCAGTTTAAACTATCAGTGTTTGAccccacgagaaattttgtttctctcgaggaaaacatggcaacgacaag VdATMT240: CAGATTGTCGTTTCCCGCCTTCAGTTTAAACTATCAGTGTTTGAtggctgggagcgagaacattaagaaagctagggagcggcccagtgct VdATMT245: CAGATTGTCGTTTCCCGCCTTCAGTTTAAACTATCAGTGTTTGActgaactaatgattgaaatactgaacgaagtgttcatggttaaattt VdATMT256: CAGATTGTCGTTTCCCGCCTTCAGTTTAAACTATCAGTGTTTGAtagcgtcctgcatgctacgcgctctgacagcaatattggatcgcgacg VdATMT264: CAGATTGTCGTTTCCCGCCTTCAGTTTAAACTATCAGTGTTTGAaattgttagtgggcgtactgggaggctcaatctcctggcgcaacaccc VdATMT314: CAGATTGTCGTTTCCCGCCTTCAGTTTAAACTATCAGTGTTTGActgaagcagattgcggataaaggtagcgtcttggtccgcgtaacgaa VdATMT316: CAGATTGTCGTTTCCCGCCTTCAGTTTAAACTATCAGTGTTTGAtaccccgccccatcgtcacttaccaggtgctgaacctttgcggctttc VdATMT320: CAGATTGTCGTTTCCCGCCTTCAGTTTAAACTATCAGTGTTTGAcacaacacgtgctccaaagcaaagtttctggagacatataaagccttt VdATMT303: CAGATTGTCGTTTCCCGCCTTCAGTTTAAACTATCAGTGTTTGAccgaactgagcaccggcccggcagaagacccgagtcatgtggccaccg VdATMT021: CAGATTGTCGTTTCCCGCCTTCAGTTTAAACTATCAGTGTTTGtgctcgtgcctgcagtgcaacagttccgcgcttgccaatgccctgcctc VdATMT239: CAGATTGTCGTTTCCCGCCTTCAGTTTAAACTATCAGTGTTTGgaggggctggagtaaagagagagagggagagatgttgttgacagactg VdATMT255: CAGATTGTCGTTTCCCGCCTTCAGTTTAAACTATCAGTGTTTGgcgcccaggagcgcgcccgagttgaagtcgtcagcctcggcgacgccca VdATMT136: CAGATTGTCGTTTCCCGCCTTCAGTTTAAACTATCAGTGTTTcaacgaacgcacgtggcacaccaccatcagcaagctactcgccatccttg
\end{abstract}

Fig. 6 Alignment of the right border (RB) sequences at the junction of T-DNA integration site of Verticillium dahliae transformants

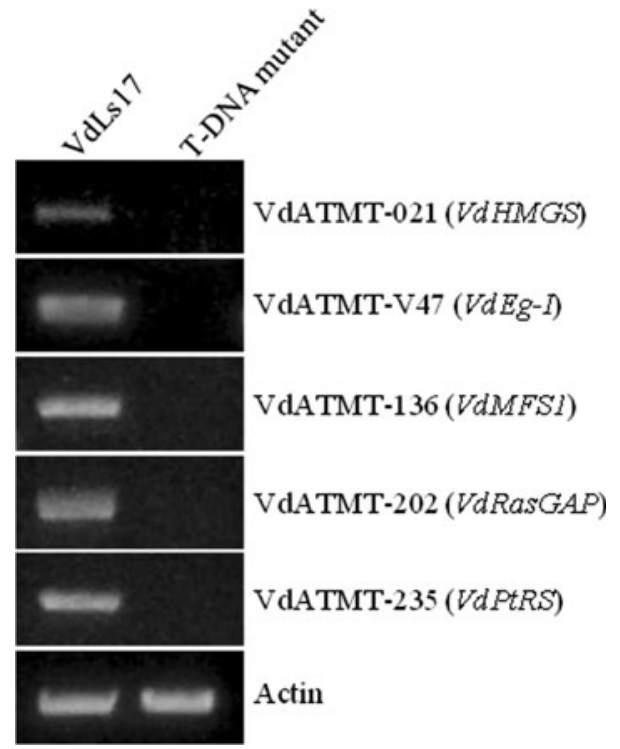

Fig. 7 Reverse-transcriptase polymerase reaction analysis of transcription of a hydroxyl-methyl glutaryl-CoA synthase (VdHMGS), an endoglucanase 1 (VdEg-1), a major facilitator superfamily (VdMFS1) transporter 1, a Ras GTPase activator (VdRasGAP), and a ProlyltRNA synthetase $(V d P t R S)$. Primers VdActF and VdActR were used for the Actin gene as a control

The flanking sequence of VdATMT-021 mutant revealed that T-DNA inserted in the hydroxymethylglutaryl-CoA synthase gene in $V$. dahliae (VDAG_10091.1). Additional confirmatory pathogenicity screening and confocal microcopy suggested an important role of a hydroxymethylglutaryl-CoA synthase gene in the pathogenicity of $V$. dahliae. The hydroxymethylglutaryl-CoA synthase gene is essential for the sterol biosynthesis pathway in various organisms [41]. In Fusarium spp., this gene plays a role in trichothecene mycotoxin production $[42,43]$.

Other candidate pathogenicity-related genes were identified in this study, but these require additional screening for confirmation. For example, in mutant VdATMT-136, T-DNA was inserted in a major facilitator superfamily transporter (MFS) gene (VDAG_09647.1). In fungi, MFS transporters play a major role in toxic compound resistance, including fungicidal resistance [44, 45]. The MFS gene disruption mutant is potentially valuable for investigating the role of the VDAG_09647.1 gene in drug resistance, or resistance to plant-produced antimicrobial compounds. Other genes of interest encode mannosyltransferase (VDAG 05742.1), Ras GTPase activator (VDAG_04078.1), C6 Zinc finger domain-containing protein (VDAG_08079.1), and a transmembrane, coiled-coil domain-containing protein (VDAG_03258.1). These genes are required for proper fungal growth, cell wall construction, virulence, and possibly for asexual morphogenesis in various fungi [46-49].

An additional aim of this study was to investigate parameters for optimal ATMT insertional mutagenesis in $V$. dahliae. Transformation efficiency in $V$. dahliae displayed dependency on co-cultivation times, similar to the situation described for other fungal systems [15, 21]. In general, more transformants can be obtained by a longer co-cultivation period in most fungi $[50,51]$. In this study, the transformation efficiency was improved by increasing the co-cultivation time up to $48 \mathrm{~h}$. With $48 \mathrm{~h}$ of 
co-cultivation, an average of 450 transformants per $5 \times 10^{6}$ conidia/ml was generated in $V$. dahliae. ATMT generates a high percentage of transformants with a single copy T-DNA compared with other conventional methods, which makes it easier to isolate the tagged gene $[15,16]$. In the current study, Southern blot analysis from randomly selected transformants showed that almost $69 \%$ of the transformants had a single copy of T-DNA integration at $36 \mathrm{~h}$ of co-cultivation. The percentage of single copy T-DNA insertion is similar to what was observed in other fungi including V. albo-atrum [21, 50-52]. The current study suggests that co-cultivations for $36 \mathrm{~h}$ as the optimum time for $V$. dahliae transformation to obtain an adequate number of single copy transformants.

In addition, the results suggest that iPCR is an efficient tool to identify the sequences adjacent to the inserted T-DNA in $V$. dahliae. Inverse-PCR is more efficient and may be a more sensitive method than TAIL-PCR in identifying the T-DNA flanking sequences in several fungi $[32,33]$. Further analysis of iPCR sequences from the right border suggests that most of the sequences recovered from the transformants were intact without any truncation, which is similar to previous reports [51, 53]. Truncation of T-DNA right border sequences was less frequent probably because VirD2 protein of Agrobacterium protects this region from degradation $[15,53]$.

In conclusion, $V$. dahliae was successfully transformed using A. tumefaciens, and the transformation efficiency of 450 mutants per $5 \times 10^{6}$ conidia is comparable to that of various fungi, including $V$. albo-atrum [21]. This protocol is useful for generating a large number of mutants carrying a single randomly inserted copy of T-DNA thus facilitating the identification of $V$. dahliae genes directly or indirectly involved in pathogenesis and survival characteristics.

Acknowledgments This research was supported in part by funding from the California Leafy Greens Research Program and the California Tomato Research Institute. The authors thank Rosa Marchebout, Francisco Hernandez, Amy Anchieta, and Dianna Hernandez for their technical assistance.

Open Access This article is distributed under the terms of the Creative Commons Attribution Noncommercial License which permits any noncommercial use, distribution, and reproduction in any medium, provided the original author(s) and source are credited.

\section{References}

1. Pegg, G. F., \& Brady, B. L. (2002). Verticillium wilts. New York: CABI Publishing.

2. Klosterman, S. J., Atallah, Z. K., Vallad, G. E., \& Subbarao, K. V. (2009). Diversity, pathogenicity, and management of Verticillium species. Annual Review of Phytopathology, 47, 39-62.

3. Hayes, R., Vallad, G. E., \& Subbarao, K. V. (2007). The inheritance of resistance to race 1 isolates of Verticillium dahliae in lettuce (Abst.). Hortscience, 42, 896.
4. Fradin, E. F., Zhang, Z., Ayala, J. C. J., Castroverde, C. D. M., Nazar, R. N., Robb, J., et al. (2009). Genetic dissection of Verticillium wilt resistance mediated by tomato Vel. Plant Physiology, 150, 320-332.

5. Maruthachalam, K., Atallah, Z. K., Vallad, G. E., Klosterman, S. J., Davis, R. M., \& Subbarao, K. V. (2010). Molecular variation among isolates of Verticillium dahliae and PCR-based differentiation of races. Phytopathology, 100, 1222-1230.

6. Schaible, L., Cannon, O. S., \& Waddoups, V. (1951). Inheritance of resistance to Verticillium wilt in a tomato cross. Phytopathology, 41, 986-990.

7. Koike, S. T., Subbarao, K. V., Davis, R. M., Gordon, T. R., \& Hubbard, J. C. (1994). Verticillium wilt of cauliflower in California. Plant Disease, 78, 1116-1121.

8. Bhat, R. G., Smith, R. F., Koike, S. T., Wu, B. M., \& Subbarao, K. V. (2003). Characterization of Verticillium dahliae isolates and wilt epidemics of pepper. Plant Disease, 87, 789-797.

9. Rauyaree, P., Ospina-Giraldo, M. D., Kang, S., Bhat, R. G., Subbarao, K. V., Grant, S. J., et al. (2005). Mutation in VMK1, a mitogen-activated protein kinase gene, affect microsclerotia formation and pathogenicity in Verticillium dahliae. Current Genetics, 48, 109-116.

10. Dobinson, K. F., Grant, S. J., \& Kang, S. (2004). Cloning and targeted disruption, via Agrobacterium tumefaciens-mediated transformation, of a trypsin protease gene from the vascular wilt fungus Verticillium dahliae. Current Genetics, 45, 104-110.

11. Wang, J. Y., Chai, Y., Gou, Y. Y., Mao, Y. B., Xu, Y. H., Jiang, W. H., et al. (2004). VdNEP, an elicitor from Verticillium dahliae, induces cotton plant wilting. Applied and Environmental Microbiology, 70, 4989-4995.

12. Tzima, A., Paplomatas, E. J., Rauyaree, P., \& Kang, S. (2010a). Roles of the catalytic subunit of cAMP dependent protein kinase A in virulence and development of the soilborne plant pathogen Verticillium dahliae. Fungal Genetics and Biology, 47, 407-415.

13. Tzima, A., Paplomatas, E. J., Rauyaree, P., Ospina-Giraldo, M. D., \& Kang, S. (2010b). VdSNF1, the sucrose non-fermenting protein kinase gene of Verticillium dahliae, is required for virulence and expression of genes involved in cell wall degradation. Molecular Plant-Microbe Interactions, 24, 129-142.

14. Klimes, A., \& Dobinson, K. F. (2006). A hydrophobin gene, $V D H 1$, is involved in microsclerotial development and spore viability in the plant pathogen Verticillium dahliae. Fungal Genetics and Biology, 43, 283-294.

15. Michielse, C. B., Hooykaas, P. J. J., van den Hondel, C. A. M. J. J., \& Ram, A. F. J. (2005). Agrobacterium-mediated transformation as a tool for functional genomics in fungi. Current Genetics, 48, 1-17.

16. Jeon, J., Park, S. Y., Chi, M. H., Choi, J., Park, J., Rho, H. S., et al. (2007). Genome-wide functional analysis of pathogenicity genes in the rice blast fungus. Nature Genetics, 39, 561-565.

17. Meyer, V., Mueller, D., Strowig, T., \& Stahl, U. (2003). Comparison of different transformation methods for Aspergillus giganteus. Current Genetics, 43, 371-377.

18. Thon, M. R., Nuckles, E. M., \& Vaillancourt, L. J. (2000). Restriction enzyme-mediated integration used to produce pathogenicity mutants of Colletotrichum graminicola. Molecular Plant-Microbe Interaction, 13, 1356-1365.

19. de Groot, M. J. A., Bundock, P., Hooykaas, P. J. J., \& Beijersbergen, A. G. M. (1998). Agrobacterium tumefaciens mediated transformation of filamentous fungi. Nature Biotechnology, 16, 839-842.

20. Chen, X., Stone, M., Schlagnhaufer, C., \& Romaine, C. P. (2000). A fruiting body tissue method for efficient Agrobacterium transformation of Agaricus bisporus. Applied and Environmental Microbiology, 66, 4510-4513.

21. Knight, C. J., Bailey, A. M., \& Foster, G. D. (2009). Agrobacterium-mediated transformation of the plant pathogenic fungus, 
Verticillium albo-atrum. Journal of Plant Pathology, 91, 745-750.

22. Hooykaas, P. J. J., Roobol, C., \& Schilperoort, R. A. (1979). Regulation of the transfer of Ti-plasmids of Agrobacterium tumefaciens. Journal of General Microbiology, 110, 99-109.

23. Bundock, P., Den Dulk-Ras, A., Beijersbergen, A., \& Hooykaas, P. J. J. (1995). Trans-kingdom T-DNA transfer from Agrobacterium tumefaciens to Saccharomyces cerevisae. EMBO Journal, 14, 3206-3214.

24. Vallad, G. E., \& Subbarao, K. V. (2008). Colonization of resistant and susceptible lettuce cultivars by a green fluorescent proteintagged isolate of Verticillium dahliae. Phytopathology, 98, 871-885.

25. Al-Samarrai, T. H., \& Schmid, J. (2000). A simple method for extraction of fungal genomic DNA. Letters in Applied Microbiology, 30, 53-56.

26. Selden, R. F. (1990). Southern blotting and hybridization (basic protocol). In F. M. Ausubel, R. Brent, R. E. Kingston, D. D. Moor, J. G. Seidman, J. A. Smith, \& K. Struhl (Eds.), Current protocols in molecular biology (Vol. 1, pp. 2.9.1-2.9.10). New York: Wiley.

27. Carroll, A., Sweigard, J. A., \& Valent, B. (1994). Improved vectors for selecting resistance to hygromycin. Fungal Genetics Newsletter, 41, 22.

28. Ochman, H., Gerber, A. S., \& Hartl, D. L. (1988). Genetic application of an inverse polymerase chain reaction. Genetics, $120,621-623$.

29. Klosterman, S. J., \& Hayes, R. J. (2009). A soilless Verticillium wilt assay using an early flowering lettuce line. Plant Disease, 93, 691-698.

30. Brunner, E., Domhof, S., \& Langer, F. (2002). Nonparametric analysis of longitudinal data in factorial experiments. New York: Wiley.

31. Shah, D. A., \& Madden, L. V. (2004). Nonparametric analysis of ordinal data in designed factorial experiments. Phytopathology, 94, 33-43.

32. White, D., \& Chen, W. (2006). Genetic transformation of Ascochyta rabiei using Agrobacterium-mediated transformation. Current Genetics, 49, 272-280.

33. Meng, Y., Patel, G., Heist, M., Betts, M. F., Tucker, S. L., Galadima, N., et al. (2007). A systematic analysis of T-DNA insertion events in Magnaporthe oryzae. Fungal Genetics and Biology, 44, 1050-1064.

34. Altschul, S. F., Gish, W., Miller, W., Myers, E. W., \& Lipman, D. J. (1990). Basic local alignment search tool. Journal of Molecular Biology, 215, 403-410.

35. Talhinhas, P., Muthumeenakshi, S., Martins, J. N., Oliveira, H., \& Sreenivasaprasad, S. (2008). Agrobacterium-mediated transformation and insertional mutagenesis in Colletotrichum acutatum for investigating varied pathogenicity lifestyles. Molecular Biotechnology, 39, 57-67.

36. De Lorenzo, G., Castoria, R., \& Cervone, F. (1997). Fungal invasion enzymes and their inhibition. In K. Esser \& P. A. Lemke (Eds.), Plant relationship, part-A. The mycota (Vol. 5, pp. 61-83). Berlin: Springer-Verlag.

37. Valaskova, V., \& Baldrian, P. (2006). Degradation of cellulose and hemicelluloses by the brown rot fungus Piptoporus betulinus production of extracellular enzymes and characterization of the major cellulases. Microbiology, 152, 3613-3622.
38. Gough, C. L., Dow, J. M., Barber, C. E., \& Daniels, M. J. (1988). Cloning of two endoglucanase genes of Xanthomonas campestris pv campestris: Analysis of the role of the major endoglucanase in pathogenesis. Molecular Plant-Microbe Interaction, 1, 275-281.

39. Roberts, D. P., Denny, T. P., \& Schell, M. A. (1988). Cloning of the egl gene of Pseudomonas solanacearum and analysis of its role in phytopathogenicity. Journal of Bacteriology, 170, 1445-1451.

40. Novo, M., Pomar, F., Gayoso, C., \& Merino, F. (2006). Cellulase activity in isolates of Verticillium dahliae deferring in aggressiveness. Plant Disease, 90, 155-160.

41. de Souza, W., \& Rodrigues, J. C. F. (2009). Sterol biosynthesis pathway as target for anti-trypanosomatid drugs. Interdisciplinary Perspectives on Infectious Diseases, 2009, 1-19.

42. Goswami, R. S., \& Kistler, H. C. (2004). Heading for disaster: Fusarium graminearum on cereal crops. Molecular Plant Pathology, 5, 515-525.

43. Peplow, A. W., Tag, A. G., Garifullina, G. F., \& Beremand, M. N. (2003). Identification of new genes positively regulated by Tri19 and regulatory network for trichothecene mycotoxin production. Applied and Environmental Microbiology, 69, 2731-2736.

44. Kapoor, K., Rehan, M., Kaushiki, A., Pasrija, R., Lynn, A. M., \& Prasad, R. (2009). Rational mutational analysis of a multidrug MFS transporter CaMdr1p of Candida albicans by employing a membrane environment based computational approach. PLOS Computational Biology, 5, 1-11.

45. Prasad, R., \& Kapoor, K. (2005). Multidrug resistance in yeast Candida. International Review of Cytology, 242, 215-248.

46. Grimme, S. J., Colussi, P. A., Taron, C. H., \& Orlean, P. (2004). Deficiencies in the essential Smp3 mannosyltransferase block glycosylphosphatidylinositol assembly and lead to defect in growth and cell wall biogenesis in Candida albicans. Microbiology, 150, 3115-3128.

47. Harispe, L., Portela, C., Scazzocchio, C., Penalva, M. A., \& Gorfinkiel, L. (2008). Ras GTPase-activating protein regulation of actin cytoskeleton and hyphal polarity in Aspergillus nidulans. Eukaryotic Cell, 7, 141-153.

48. Parra, I. F., Vranes, M., Kamper, J., \& Martin, J. P. (2006). Biz1, a zinc finger protein required for plant invasion by Ustilago maydis, regulates the levels of a mitotic cyclin. Plant Cell, 18, 2369-2387.

49. Yamamura, Y., \& Shim, W. B. (2008). The coiled-coil proteinbinding motif in Fusarium verticillioides Fsr1 is essential for maize stalk rot virulence. Microbiology, 154, 1637-1645.

50. Mullins, E. D., Chen, X., Romaine, P., Raina, R., Geiser, D. M., \& Kang, S. (2001). Agrobacterium-mediated transformation of Fusarium oxysporum: An efficient tool for insertional mutagenesis and gene transfer. Phytopathology, 91, 172-180.

51. Maruthachalam, K., Nair, V., Rho, H. S., Choi, J., Kim, S., \& Lee, Y. H. (2008). Agrobacterium tumefaciens-mediated transformation in Colletotrichum falcatum and C. acutatum. Journal of Microbiology and Biotechnology, 18, 234-241.

52. Rho, H. S., Kang, S., \& Lee, Y. H. (2001). Agrobacterium tumefaciens-mediated transformation of the plant pathogenic fungus, Magnaporthe grisea. Molecules and Cells, 12, 407-411.

53. Choi, J., Park, J., Jeon, J., Chi, M. H., Goh, J., Yoo, S. Y., et al. (2007). Genome-wide analysis of T-DNA integration into the chromosomes of Magnaporthe oryzae. Molecular Microbiology, 66, 371-382. 